\title{
The effects of cognitive set on the skin conductance orienting response to tones of the pitch of musical notes ${ }^{1)}$
}

\author{
MiCHIHIRO, Kazumi \\ Kwansei Gakuin University, Nishinomiya-shi, 663, Japan
}

\begin{abstract}
The present study examined the effects of cognitive set on the skin conductance orienting response (SCR OR). Three tones, corresponding in pitch to notes $\mathrm{C}, \mathrm{E}$, and $\mathrm{G}$ on the musical scale, were used. Subjects were first presented with pairs of $\mathrm{C}$ and $\mathrm{E}$ tones until a habituation criterion was reached. Following this, they were given another pairs of $\mathrm{C}$ and $\mathrm{G}$ tones until a habituation criterion. Twenty-eight female college volunteers were divided into two groups, according to their cognitive set perceiving tones as simple physical tones or as musical notes, that is, Tone Group $(\mathrm{N}=15)$ and Musical Scale Group $(\mathrm{N}=13)$. The results indicated that Musical Scale Group showed significantly slower habituation to both pairs of tones and more pronounced SCR OR to the change in tone pairing compared to Tone Group.
\end{abstract}

Key words: cognitive set, skin conductance response, stimulus change habituation

【要 約】本研究は, 定位性の皮膚コンダクタンス反応の生起に関わる認知的構光の効果を検討するこ とを目的とした．皮膚コンダクタンス反応を誘発する刺激として，八長調音階のド（C），ミ（E），ソ （G）にあたる音を用いた．28名の女子短大生全員に，まずドの音を 1 秒間提示，100ミリ秒の間隔を招い てミの音を 1 秒間提示する刺激対をハビチュエーション基準に達するまで反復提示し，引き続いてドとソ の刺激対を同じくハビチュエーション基準に達するまで反復提示した。これらの被験者を，実駼終了後の 質問の回答によって，音が音階と符号していることに気づいて音階名をあてはめて聞いていた音階群（N =13）音階群と, 音階に気づかずに聞いていた音群 $(\mathrm{N}=15)$ とに分けた. その結果, 音階群で刺激対の変 化に対して有意に大きな定位性皮虚コンダクタンス反応の生起とハビチュエーションの遅れが認められ た。

Maltzman (1979a, 1979b) proposed that the "state" of an organism predetermines the occurrence of orienting responses(ORs). He explained the "state" using the concept of cortical set or dominant focus, which refers to a focus of excitation in the central nervous system. Dominant foci, according to Maltzman, provide a physiological basis for stimulus significance, and are established by instructions or are the result of thinking (e. g., Maltzman, 1977; Maltzman, Gould, Pendery, \& Wolff, 1982; Maltzman \& Langdon, 1982; Pendery \& Maltzman, 1977).

Maltzman examined the effects of instruc-

1) This study was supported by a Grant-in-Aid for Scientific Research from Ministry of Education (No. 63790030). The author is graterul to Prof. Y. Miyata of Kwansei Gakuin University and Associate Prof. T. Muranaka and Mrs. M. L. Sato of Niimi Women's College for aid in producing the manuscript. 
tions or thinking on the $\mathrm{OR}$ and indicated that the occurrence of ORs were determined by the novelty and/or the noteworthiness, that is, the signal value of stimulus; an involuntary $O R$ and a voluntary OR. He formulated the physiological model of voluntary OR using the concept of cortical set and asserted that the stimulus significance is an important determiner of ORs. Maltzman has explored the neuronal model mediating between stimulations and physiological orienting responses.

On the other hand, we have used the cognitive set. Our studies aim to construct the psychological concept explaining orienting behaviours represented by SCR and define the significance as a cognitive factor affecting ORs with cognitive sets. As we are interested in these psychological functions and examine the relationship between psychological factors and physiological responses, we have not refered to physiological concept.

Michihiro, Muranaka, and Miyata (1984) examined the effects of instructions on the ORs, which required subjects to attend to or ignore tone stimuli in order to induce two different significance of tones. The results of OR responsivity indicated the effects of different significance; the former significance increased the responsivity to tones and the later signficance seemed to facilitate habituation. Michihiro, Muranaka, and Miyata (1986) designed an experimental situation in which subjects had to discover a rule of tone-presentation. On the tone omission trial, 7 of 9 subjects who were informed that the rule might be changed showed the skin conductance orienting response (SCR OR) to a missing stimulus, while only 1 of 9 subjects who were not informed on the rule of stimulus showed SCR OR. Concerning missing tone, the post-experimental reports of these subjects were distinguished as followes: the informed subjects expected that the rule would be changed, and the other subjects judged that the experiment was over at the time of discovering the rule. This result indicated that the stimulus change of tone omission was not enough to elicit an $\mathrm{OR}$ and an occurrence of OR to missing stimulus would be affected by subjective' factor, a cognitive factor concerning omission.

The serious problems in clarifying the effects of cognitive sets on ORs are lying in how to control the subject' cognitive states and to get more clear cognitive activities. Michihiro (1987) sought to examine the SCR to the tones of the pitch of musical notes by controlling the cognitive set; one half of the subjects were instructed to listen to tones as physical tones and the other half were instructed to listen to them as musical notes. But the results did not reveal the effects of different cognitive sets on the SCR habituation to tones and the SCR magnitude to tone change. These ambiguous results may be partially concerned with the fact of "autogeneous" cognitive sets, as the subjects reported, which occurred beyond instructions; some of subjects, who had been instructed to listen to stimuli only as physical tones, perceived tones as musical notes, whether or not they had a peculiar musical experience. Although this study suggested the effects of different cognitive set on SCR to tones, it is necessary to remove such a confusion between instructions and autogeneous cognitive sets. From this reason, the present study tried to examine the effects of autogeneous cognitive sets. Differing from the previous study (Michihiro, 1987), where the pair of two same tones were changed into another pair of two different pitch tones after SCR habituation, the present study did not inform that tones consisted of musical notes and tried to induce the different types of perception resulting from autogeneous cognitive sets. Using such an improved procedure, the present study re-examined the effects of different cognitive sets on SCR OR to tones. 
Two pair of different pitched of tone was changed to another one following to attain the habituation and SCR was used as the index of the OR.

\section{Method}

\section{Subjects}

The subjects were 28 female college students in the nursing course and the preparatory school educational course, aged 18-21 years old ( $\mathrm{X}=19.6 \mathrm{yrs})$.

\section{Apparatus}

The auditory stimuli were an $525 \mathrm{~Hz}$, an $658 \mathrm{~Hz}$ and an $781 \mathrm{~Hz}$ tone produced by a Yamaha MSX personal computer and an FM music macro and presented to subjects via Sony Dynamic Stereo Headphones (DR-3). Intensity of tones was $70 \mathrm{~dB}$ and the background white-noise was about $50 \mathrm{~dB}$ measured by a sound level meter ( $\mathrm{C}$ scale). Skin resistance was measured using Beckman $\mathrm{Ag}-\mathrm{AgCl}$ electrodes ( $9 \mathrm{~mm}$ diameter) attached to the center of the palm and the distal phalanx of the third finger of the subject's left hand. The electrodes were filled with Beckman electrode paste and coupled to a Hewlett Packard 3438A digital multimeter including a constant voltage circuit $(.5 \mathrm{~V})$. Skin resistance was recorded at 3 or 4 data per second and transformed into conductance by an NEC PC-8001 personal computer system through an IEEE 488 bus cable coupled to the digital multimeter.

\section{Procedure}

Subjects were seated in a sound proof booth. After headphones and electrodes were attached, there was a 7 -min rest period during which a $70 \mathrm{~dB}, 1042 \mathrm{~Hz}$ was presented once for $2 \mathrm{~s}$ and SCR to the tone was measured in order to assess SCR responsivity among subjects. Then the subjects were instructed to listen carefully to a pair of tones. They were told that the tones might be changed during the experimental session, and that if they noticed the change in tones, they would be required to describe verbally after the experiment how they perceived the change in tones.

The first pair of tones, an $525 \mathrm{~Hz}$ tone ("C" on the musical scale) and an $658 \mathrm{~Hz}$ tone ("E") ( $C-E$ pairing), was presented repeatedly until the habituation criterion of two successive non responses was met. The second pair of tones, an $525 \mathrm{~Hz}$ tone ("C") and an $781 \mathrm{~Hz}$ (" $\mathrm{G}$ ") $(C-G$ pairing), was then presented repeatedly until the same habituation criterion was attained. The duration of each tone was $1 \mathrm{~s}$, with an interval of $100 \mathrm{~ms}$ between the paired tones. The interstimulus interval was $30 \mathrm{~s}$ on average.

After electrodes and headphones were removed, the subjects were asked to answer the following questions: "Did you notice the change in the pair of tones, and in case you did, how did the pair of tones change?" The subjects were classified into two groups differing in cognitive sets based on this post-experiment interrogation. Fifteen subjects who reported that the second tone in the $C-G$ pair had a higher pitch than that in the $C-E$ pair were classified as the Tone Group, who were not aware of the tones corresponding to musical notes. Thirteen subjects who reported that the pair "Do and Mi" was changed to the pair "Do and So" were classified as the Musical Scale Group. Although several subjects had any musical experiences of playing an instrument or singing, the Musical Scale Group were not always constructed with such subjects and the Tone Group involved some of them.

\section{Skin conductance measures}

SCRs were measured if they occurred within a 1-4.5-s window following the tone onset. SCR amplitude was obtained by measuring the difference between the value at stimulus onset and the first peak. Differences 
of less than $500 \Omega(0.16 \mu \mathrm{S})$ were scored as non responses. The square root transformation was employed prior to statistical analysis. A significance level of .05 was adopted for all comparisons.

\section{Results}

The SCR responsivity to the $1042 \mathrm{~Hz}$ tone presented during the rest period was not different between groups(Tone Group: 1.06 $\mu \mathrm{S}(\mathrm{SD}=0.27) ; \quad$ Musical Scale Group: 1.31 $\mu \mathrm{S}(\mathrm{SD}=0.49))$.

The magnitude to the first presentation of the $C-E$ pairing was $1.26 \mu \mathrm{S}(\mathrm{SD}=0.49)$ for the Tone Group and $1.39 \mu \mathrm{S}(\mathrm{SD}=0.39)$ for the Musical Scale Group. The difference was not statistically significant $(t(26)<1)$.

The mean number of trials to reach the habituation criterion with the $C-E$ pairing was shown on the left column Table 1, and the same result with $C-G$ pairing was shown on the right column. Analyses of trials-to-habituation scores showed that the Musical Scale Group required more trials to reach habituation than did the Tone Group in each of pairing condition $(C-E: t(26)=3.75 ; C-G: t(26)=3.08)$.

Table 1 Mean number of trials to reach the habituation criterion for groups in the $C-E$ and $C-G$ pairing session

\begin{tabular}{llll}
\hline & & \multicolumn{2}{c}{ Sessions } \\
\cline { 3 - 4 } Groups & & C-E & C-G \\
\hline Tone & Mean & 2.6 & 0.4 \\
& SD & 1.7 & 0.6 \\
& Range & $1-7$ & $0-2$ \\
Musical & Mean & 7.3 & 2.1 \\
Scale & SD & 4.9 & 2.1 \\
& Range & $2-20$ & $0-7$ \\
\hline
\end{tabular}

The mean SCR magnitudes on the first three trials with the $C-E$ pairing are presented in Figure 1. The significant difference was obtained only on the second trial, where the
Musical Scale Group showed a larger SCR than the Tone Group $(t(26)=2.67)$.

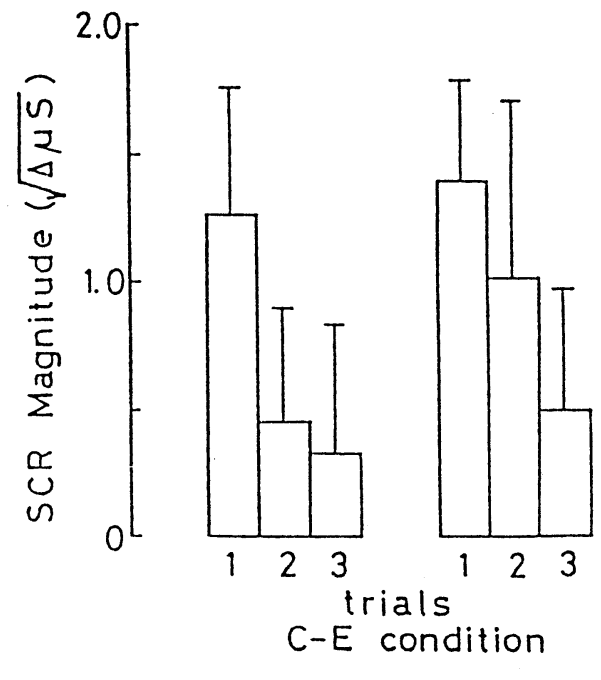

$$
\text { Tone M-Scale }
$$

Fig. 1 The mean SCR magnitude to paired tones of $525 \mathrm{~Hz}$ and $658 \mathrm{~Hz}(C-E$ pairing) on the first three trials.

The mean SCR magnitude to the first presentation of the $C-G$ pairing was shown in Table 2. The mean SCR magnitude in the Musical Scale Group was significantly larger than that in the Tone Group $(t(26)=3.67)$. The number of responders to the first presentation of the $C-G$ pairing was 5 out of 15 subjects in the Tone Group and 10 out of 13 in the Musical Scale Group. The difference was statis-

Table 2 Mean SCR magnitude to tone change for two groups and mean SCR magnitude to it for responders in groups

\begin{tabular}{llll}
\hline & & \multicolumn{2}{c}{ Groups } \\
\cline { 2 - 4 } & SCR & Tone & M.Scale \\
\hline A11 & Mean & 0.29 & 1.20 \\
subjects & SD & 0.43 & 0.80 \\
Responders $\%$ & 33.3 & 76.9 \\
& Mean & 0.87 & 1.56 \\
& SD & 0.26 & 0.53 \\
\hline
\end{tabular}


tically significant $\left(\chi^{2}(1)=5.32\right)$. The mean SCR magnitude for responders to the first presentation of $C-G$ pairing was statistically differed between groups $(t(13)=2.56)$.

\section{Discusstion}

The present study examined how cognitive sets influenced on SCR responsivity to tones and tone change. The previous study(Michihiro, 1987) had tried to control the two different cognitive sets to tones in the pitch of musical notes by giving two types of instruction, but the effects of two different instructions was not clear on SCR responsivity to tones. The present study improved the combination of tone stimuli, and did not give the subjects any information on the nature of presented tones since the autogeneous cognitive sets should be considered.

Although all subjects were not informed that tones were corresponding in pitch to musical notes before tone presentation, 13 subjects of them reported that they perceived tones as "Do", "Mi", and "So", respectively. The others reported that they perceived tones just like pips, a buzzer and sirens of an ambulance, for example. Subjects were classified, according to their reports, into two groups: Musical Scale Group and Tone Group.

It was hypothesized that such differences in two types of cognitive sets would be reflected on SCR responsivity to tones. The analyses of SCR to tones revealed that SCR of Musical Scale Group were more sensitive to tones, and showed a slower habituation that of Tone Group. Especially in the first $C-G$ trial, SCR responsivity to tone change was eminent between groups. These results supported our hypothesis.

There seemed to be an association of autogeneous cognitive sets with musical experiences, and inquiry was made of the subjects for both groups about their musical trainings.
The results denied such an association, for almost all subjects had experienced training of playing the piano or the other instruments, chorusing, though there was no specialists. The Musical Group involved some subjects who had taken no special musical training, while in the Tone Group the reverse was the case.

Cognitive set is affected by emotions and motives, and affects learning and perception. And then it acts controlling the sensation of stimulation. We are interested in the relationship between psychological factors and physiological responses, especially the function of cognitive set on pyhsiological responses. We have adopted SCRs as the index of OR, that is, a physiological state, while we have made subjects establish a certain cognitive set by means of instructions, stimulus situations and taken the self-report from subjects after experiments. Bur it was so difficult for them to report the details. It is desirable to get their self-reports immediately following stimulation. If so, we could realize the relationship between self-reports and elicitaions of SCR more precisely. At present, we try to examine getting the self-report after every trials.

\section{References}

Maltzman, I. 1977 Orienting in classical conditioning and generalization of the galvanic skin response to words: An overview. J. Exp. Psychol.: Gen, 106, 111-119.

Maltzman, I. 1979a Orienting reflexes and significance: A reply to O'Gorman. Psychophysiology, 16, 274-282.

Maltzman I. 1979b Orienting reflexes and classical conditioning in humans. In H. D. Kimmel. E. H van Olst, and J. F. Orlebeke (Eds.), The orienting reflex in humans. New York: Erlbaum.

Maltzman, I., Gould, J., Pendery, M., and Wolff, C. 1982 Task instructions as a determiner of the GSR index of the orienting reflex. 
Physiol. Psychol., 10, 253-238.

Maltzman, I. and Langdon, B. 1982 Novelty and significance as determiners of the GSR index of the orienting reflex. Physiol. Psychol., 10, 229-234.

Michihiro, K. 1987 Effects of cognitive set upon the orienting skin conductance response. Jpn. J. Physiol. Psychol. Psychophysiol., 5, 123128. (in Japanese with an English abstract)

Michihiro, K., Muranaka, T., and Miyata, Y. 1984 Effects of instructions on the skin conductance response. Jpn. Psychol. Res., 26, 159-167.
Michihiro, K., Muranaka, T., and Miyata, Y. 1986 The effects of cognitive set on the electrodermal orienting response. Psychophysiology, 23, 642-647.

Pendery, M. and Maltzman, I. 1977 Instructions and the orienting reflex in "semantic conditioning" of the galvanic skin response in an innocuous situation. J. Exp. Psychol.: Gen., 106, $120-140$. 